\title{
ANALISIS AKTIVITAS PEMBELAJARAN IPS BERBASIS DARING PADA MASA PANDEMI COVID-19 BAGI PESERTA DIDIK SMP D] KECAMATAN TAHUNAN KABUPATEN JEPARA
}

\section{Meta Febiani, Aisyah Nur Sayidatun Nisa ${ }^{\bowtie}$}

Social Science Education Department, Faculty of Social Science, Universitas Negeri Semarang, Indonesia

\begin{abstract}
Info Artikel
Sejarah Artikel:

Disubmit: Oktober 2020

Direvisi: Januari 2021

Diterima: Januari 2021

Keywords:

Social Science Learning

Activity, Learning From

Home, Students, Junior

High School.(;)

Abstrak

Pandemi COVID-19 membawa dampak dan transformasi secara masif terhadap tatanan kehidupan masyarakat serta mempengaruhi berbagai bidang salah satun ya bidang pendidikan. Seluruh jenjang pendidikan di Indonesia harus menyelenggarakan pembelajaran dari rumah, salah satunya dalam proses pembelajaran IPS di Sekolah Menengah Pertama (SMP). Artikel ini bertujuan untuk membahas dan memberikan gambaran mengenai aktivitas pembelajaran IPS berbasis daring bagi peserta didik SMP di Kecamatan Tahunan, Kabupaten Jepara. Metode penelitian yang digunakan adalah metode kualitatif. Hasil penelitian menunjukkan bahwa (1) Aktivitas pembelajaran IPS berbasis daring oleh peserta didik jenjang SMP di Kecamatan Tahunan Kabupaten Jepara dilakukan dengan memanfaatkan teknologi digital melalui aplikasi pembelajaran online (2) Terdapat banyak kendala yang dialami oleh peserta didik jenjang SMP di Kecamatan Tahunan Kabupaten Jepara dalam proses pembelajaran IPS berbasis daring salah satunya mengenai sulitnya memahami materi IPS
\end{abstract}

Abstract

The COVID-19 pandemic has had a massive impact and transformation on people's lives and has affected various fields, one of which is education. all levels of education in Indonesia must provide learning from home, one of them is in social studies learning in junior high school. This article aims to discuss and provide an overview of online-based social studies learning activities for junior high school students in the Tahunan District, Jepara Regency. The research method used is qualitative methods. The results showed that (1) Online-based social studies learning activities by junior high school level students in the Annual District of Jepara Regency were carried out by utilizing digital technology through online learning applications (2) There were many obstacles experienced by junior high school level students in the Annual District of Jepara Regency. One of the online-based social studies learning processes is about the difficulty of understanding social studies material

(C) 2021 Universitas Negeri Semarang

\begin{tabular}{lr}
\hline Alamat korespondensi: & ISSN 2252-7133 \\
Contoh: & E-ISSN 2548-4648 \\
Jl. Wonosari, Kecamatan Tahunan, Kabupaten Jepara & \\
Jawa Tengah,59427 & \\
E-mail: mettafebiani@students.unnes.ac.id; & \\
$\quad$ aisyah8816@mail.unnes.ac.id &
\end{tabular}




\section{PENDAHULUAN}

Saat ini negara-negara di berbagai penjuru dunia tengah di hadapkan pada situasi sulit akibat mewabahnya pandemi COVID-19. Berdasarkan pemaparan World Health Organization (WHO) Coronaviruses (Cov) merupakan suatu virus yang menginfeksi sistem pernapasan, infeksi virus tersebut dikenal sebagai Coronavirus Disease 2019 (COVID-19). Pandemi COVID-19 telah menyebar hampir ke seluruh negara yang ada di dunia, tak terkecuali Indonesia. Pandemi ini membawa dampak dan transformasi secara masif terhadap tatanan kehidupan masyarakat serta mempengaruhi berbagai bidang seperti kesehatan, ekonomi, pendidikan, sosial budaya, dan lain sebagainya. Pendidikan menjadi salah satu bidang yang mengalami banyak perubahan.

Undang-Undang Republik Indonesia Nomor 20 Tahun 2003 tentang sistem pendidikan nasional, pendidikan merupakan suatu usaha sadar dan terencana dalam mewujudkan suasana belajar dan proses pembelajaran agar peserta didik dapat mengembangkan potensi dirinya secara aktif guna memiliki kekuatan spiritual keagamaan, pengendalian diri, kepribadian, kecerdasan, akhlak mulia, serta keterampilan yang diperlukan dirinya dan masyarakat. Tak pelak, bidang pendidikan di Indonesia mengalami perubahan yang sangat signifikan akibat pandemi COVID-19. Pemberlakuan kebijakan physical distancing menjadi dasar penerapan learning from home yang menempatkan pendidik dan peserta didik untuk mau tidak mau harus menjalankan pembelajaran jarak jauh dengan sistem daring sebagai alternatif agar proses pembelajaran dapat tetap berjalan selama pandemi COVID-19.

Pemerintah telah mengeluarkan kebijakan perihal belajar dari rumah melalui Surat Edaran Mendikbud Nomor 36962/MPK.A/HK/2020 yang menyatakan bahwasanya pembelajaran harus dilakukan secara daring agar supaya COVID-19 dapat dicegah penyebarannya (Karnawati dan
Mardiharto, 2020). Seluruh jenjang pendidikan di Indonesia mulai dari PAUD, TK, Sekolah Dasar, Sekolah Menengah Pertama, Sekolah Menengah Atas, dan Perguruan Tinggi dipaksa melakukan transformasi dan adaptasi secara tiba-tiba untuk melakukan pembelajaran dari rumah melalui berbagai media daring (online). Disatu sisi, Era Revolusi Industri 4.0 telah mendekatkan masyarakat dengan perkembangan teknologi digital sehingga memudahkan fase transformasi pembelajaran konvensional menjadi pembelajaran daring di masa pandemi COVID-19. Namun disisi lain, kondisi tersebut menuntut pendidik maupun peserta didik untuk menyesuaikan diri dengan kebiasaan baru yang mana sebelumnya belum pernah dilakukan mengingat proses belajar mengajar biasanya dilakukan secara konvensional dengan tatap muka di dalam kelas.

Pembelajaran daring secara eksplisit mengindikasikan bahwasanya seluruh penyampaian materi pembelajaran kepada peserta didik dilakukan dengan memanfaatkan teknologi digital sebagai media pembelajaran. Hal serupa terjadi pada pembelajaran IPS di Sekolah Menengah Pertama. Merujuk pada kurikulum 2013 Mata Pelajaran IPS untuk SMP/MTs bahwa IPS merupakan mata pelajaran yang mempelajari dan mengkaji mengenai isu-isu sosial dengan unsur kajiannya meliputi konteks fakta, peristiwa, konsep, dan generalisasi (Supardan, 2015 :17). Menurut Susanto (2016 : 6) Ilmu Pengetahuan Sosial merupakan integrasi dari berbagai cabang ilmuilmu sosial dan humaniora yang meliputi sejarah, geografi, sosiologi, ekonomi, budaya, hukum, dan politik.

Aktivitas pembelajaran IPS adalah suatu proses pemberian pengetahuan dan pengalaman belajar kepada peserta didik melalui serangkaian kegiatan yang direncanakan secara efektif dan rinci sehingga peserta didik memperoleh pengetahuan mengenai materi yang dipelajari. Tujuan pembelajaran IPS ialah untuk mempersiapkan peserta didik menjadi warga negara yang baik 
(good citizen) serta mengembangkan kemampuan penalaran dan berpikir kritis peserta didik dalam pengambilan keputusan terhadap setiap problematika yang dihadapi (Suwarna AlMuchtar, 2014 : 15-16). Sedangkan menurut Jack R. Fraenkel (1980) dalam Somantri (2010 : 99-100) tujuan pembelajaran IPS terdiri atas empat kategori yakni pengetahuan, keterampilan, sikap, dan nilai.

Kegagalan pembelajaran IPS di sekolah-sekolah di Indpnesia terjadi lantaran proses pembelajaran IPS lebih menekankan pada aspek pengetahuan, konsep-konsep, dan fakta yang bersifat hafalan belaka, begitu kental akan materi, belum membiasakan pengalaman nilai-nilai sosial, dan kurang diarahkan pada suatu pembelajaran yang bermakna dan bermanfaat bagi kehidupan peserta didik sehingga memerlukan adanya suatu inovasi pembelajaran (Gunawan, 2013 : 88,113). Menurut Hasan (2007) dalam Somantri (2010 : 8-9) berbagai permasalahan pembelajaran IPS selama ini, mengindikasikan bahwa pembelajaran IPS kerap kali disajikan dalam bentuk faktual, guru IPS hanya mengejar target tercapainya materi kurikulum, tidak menekankan pada proses pembelajaran IPS sehingga pembelajaran yang dilakukan selalu terkesan jenuh dan membosankan bagi peserta didik.

Di masa pandemi COVID-19 pembelajaran daring mata pelajaran IPS tentunya dilakukan dengan memanfaatkan teknologi digital. Proses belajar mengajar dilakukan melalui berbagai media online berupa aplikasi maupun platform pembelajaran online. Hal ini merupakan tantangan sekaligus peluang bagi guru IPS. Pembelajaran daring menuntut seorang guru IPS untuk mampu melakukan berbagai inovasi dengan memanfaatkan teknologi digital yang sudah ada, baik metode, media, dan model pembelajaran yang harus dipersiapkan secara matang. Melalui pembelajaran daring inilah guru IPS dapat menciptakan proses pembelajaran yang bermakna bagi peserta didik. Di sisi lain, peserta didik juga harus mampu beradaptasi dengan berbagai perubahan yang terjadi, mengingat untuk dapat bersaing secara global peserta didik harus mampu memanfaatkan berbagai perkembangan teknologi.

Hasil observasi awal menunjukkan peserta didik yang tengah duduk di bangku SMP yang bertempat tinggal di Kecamatan Tahunan Kabupaten Jepara berasal dari sekolah dan jenjang kelas yang berbeda. Selanjutnya peserta didik mengalami kesulitan sekaligus hambatan dalam proses pembelajaran daring mata pelajaran IPS. Selain itu, peserta didik terlihat belum sepenuhnya mampu memahami dan menguasai materi yang diberikan oleh guru. Berdasarkan latar belakang tersebut, artikel ini bertujuan untuk membahas dan memberikan gambaran mengenai aktivitas pembelajaran IPS berbasis daring bagi peserta didik SMP di Kecamatan Tahunan, Kabupaten Jepara sehingga peneliti berfokus untuk mengetahui: (1) analisis aktivitas pembelajaran IPS berbasis daring bagi peserta didik SMP di Kecamatan Tahunan, Kabupaten Jepara, (2) kendala dalam pembelajaran IPS berbasis daring bagi peserta didik SMP di Kecamatan Tahunan, Kabupaten Jepara, (3) solusi terhadap kendala pembelajaran IPS berbasis daring bagi peserta didik SMP di Kecamatan Tahunan, Kabupaten Jepara.

\section{METODE}

Metode yang digunakan dalam penelitian ini adalah metode kualitatif dengan analisis deskriptif. Menurut Mantra (2004) dalam Siyoto S (2015 : 27) menyatakan metode kualitatif sebagai prosedur penelitian yang menghasilkan data secara deskriptif yakni berupa kata-kata atau lisan dari orang atau perilaku yang dapat diamati. Instrumen yang digunakan dalam penelitian ini adalah peneliti itu sendiri, pedoman wawancara, dan dokumentasi. Teknik pengumpulan data dilakukan dengan cara observasi, wawancara, dan dokumentasi. Wawancara dilakukan secara langsung dengan informan utama, yaitu peserta didik. Lokus penelitian dilakukan di Kecamatan Tahunan, 
Kabupaten Jepara. Teknik analisis data dalam penelitian ini meliputi pengumpulan data, analisis data, penyajian data yang ditampilkan dalam bentuk deskripsi atau narasi didukung dokumentasi aktivitas pembelajaran IPS berbasis daring, dan penarikan kesimpulan.

\section{PEMB AHASAN}

\section{Aktivitas Pembelajaran IPS Berbasis Daring Bagi Peserta Didik SMP Di Kecamatan Tahunan Kabupaten Jepara}

Pembelajaran merupakan suatu kegiatan dalam wujud interaksi antara pendidik atau sumber belajar dengan peserta didik dalam suatu lingkungan belajar. Menurut Santrock (2011 : 266) pembelajaran (learning) dapat diartikan sebagai pengaruh yang permanen atas perilaku, pengetahuan, serta keterampilan berpikir yang di dapat melalui sebuah pengalaman. Pembelajaran IPS di tingkat Sekolah Menengah Pertama (SMP) berdasarkan kurikulum IPS saat ini dilakukan dengan model pembelajaran terpadu yang menyatukan seluruh ilmu-ilmu sosial dalam satu bidang studi (BSNP, 2007).

Masa pandemi COVID-19 seluruh kegiatan belajar mengajar dialihkan dari sistem luring menjadi sistem daring. Pun dengan pembelajaran IPS di tingkat SMP. Berdasarkan hasil wawancara dengan sejumlah informan, pembelajaran IPS berbasis daring dilakukan dengan memanfaatkan teknologi digital berupa aplikasi pembelajaran online. Pembelajaran IPS tingkat SMP dilakukan selama 2 kali dalam satu minggu. Dalam melaksanakan proses pembelajaran mata pelajaran IPS guru memanfaatkan aplikasi berupa google classroom, Whatsapp Group, dan Telegram. Dalam aktivitas pembelajaran IPS berbasis daring tidak ada tahap pelaksanaan langkah-langkah aktivitas pembelajaran tertentu dari guru IPS, setiap perkembangan materi maupun pemberian tugas diberikan melalui aplikasi seperti google clasroom, dan peserta didik dapat mengakses sesuai dengan jadwal pelajaran IPS.
Biasanya sebelum memulai pembelajaran IPS berbasis daring guru memberikan salam dan sapa terlebih dahulu melalui Whatsapp Group maupun Telegram dan meminta peserta didik untuk mengisi list presensi kehadiran kemudian menghimbau peserta didik untuk mengakses google classroom guna mengikuti pembelajaran IPS dengan membaca dan memahami secara mandiri materi yang telah di upload oleh guru, menjawab kuis, ataupun mengerjakan tugas.

Guru menyampaikan materi kepada peserta didik dengan memanfaatkan media pembelajaran berupa e-book ataupun video pembelajaran dari Youtube yang dapat diakses melalui sebuah link yang ditautkan oleh guru. Pemberian tugas oleh guru selama pembelajaran IPS berbasis daring lebih cenderung pada pemberian soal-soal terstruktur mengenai materi yang disampaikan. Sebagaimana hasil wawancara dengan RM (salah satu informan) memberikan pernyataan bahwa selama pembelajaran daring mata pelajaran IPS keterlibatan guru dalam proses belajar mengajar sangat sedikit, guru hanya hadir berkisar 10-20 menit diawal pembelajaran, dan selebihnya kegiatan pembelajaran IPS diserahkan sepenuhnya kepada masing-masing peserta didik untuk belajar secara mandiri dengan memahami materi ataupun mengerjakan tugas yang diberikan.

Aktivitas pembelajaran berbasis daring membutuhkan kolaborasi antara orang tua, guru, dan peserta didik. Terlebih orang tua, tatkala pembelajaran online yang dilakukan di rumah orang tua memiliki peran yang sangat signifikan dalam memberikan motivasi, semangat, sekaligus menjadi mentor bagi anaknya. Berdasarkan hasil wawancara, seluruh informan menyatakan bahwa orang tua mereka tidak pernah ikut campur dalam pembelajaran daring. Saat menjalankan aktivitas pembelajaran IPS melalui aplikasi google classroom tidak ada peran maupun kontribusi dari orang tua peserta didik dalam hal mendampingi ataupun sekedar memotivasi anaknya. Hal ini lantaran peserta didik yang 
duduk di bangku SMP sudah dianggap mmapu untuk belajar mandiri tanpa bantuan orang tua berbeda halnya dengan peserta didik yang masih berada di jenjang Sekolah Dasar. Pun demikian hasil wawancara dengan SR, "Setiap kali pembelajaran daring entah itu mata pelajaran IPS maupun mata pelajaran lainnya, orang tua saya tidak pernah mendampingi saya. Karena mungkin saya sudah SMP jadi sudah terkesan bisa belajar secara mandiri, selain itu di jam pelajaran juga orang tua saya bekerja atau lebih sering melakukan pekerjaan rumah".

\section{Kendala Dalam Pembelajaran IPS Berbasis Daring Bagi Peserta Didik SMP Di Kecamatan Tahunan Kabupaten Jepara}

Pembelajaran berbasis daring di tengah pandemi COVID-19 tentunya membawa dampak pada peningkatan kemampuan peserta didik dalam menggunakan atau memanfaatkan teknologi digital. Namun, Pelaksanaan pembelajaran berbasis daring kerap kali mengalami kendala ataupun kesulitan saat prosesnya. Hal serupa terjadi saat pembelajaran IPS berbasis daring oleh peserta didik yang berada pada jenjang SMP di Kecamatan Tahunan, Kabupaten Jepara. Penggunaan media digital khususnya gadget sebagai media pembelajaran daring mendatangkan berbagai kendala yang dasar seperti susahnya jaringan signal, ketersediaan kuota peserta didik yang masih terbatas, penggunaan gadget secara intens menyebabkan peserta didik cenderung mudah lelah, cenderung mudah bosan dan akhirnya tergiur oleh aplikasi lain yang lebih diminati peserta didik seperti social media ataupun game.

Kendala lain yang lebih spesifik pada pembelajaran IPS berbasis daring terletak pada guru. Berdasarkan hasil wawancara, sejumlah informan menyatakan bahwa pembelajaran IPS yang dilakukan cenderung membosankan, kurang menyenangkan, dan sama sekali tidak memunculkan motivasi peserta didik untuk semangat mempelajarinya. Dalam setiap pertemuan, guru lebih sering memberikan tugas dan kuis dibandingkan penguatan atau pemahaman mengenai materi. Guru justru terkesan lebih sering memberikan tugas tanpa menjelaskan materi terlebih dahulu. Sebagaimana ditujukkan dari hasil wawancara dengan SW bahwa guru sangat jarang memberikan materi melalui google classroom, guru kerap kali hanya memberikan tugas saja tanpa menjelaskan materi kepada peserta didik. Sehingga peserta didik mengalami kesulitan dalam memahami materi, dan kemudian peserta didik mencari sumber materi yang berasal dari internet untuk mengerjakan tugas yang diberikan guru mengingat seringnya materi tugas yang diberikan oleh guru tidak dapat ditemukan di buku paket atau buku referensi lain milik peserta didik. Hal demikian justru berimbas pada perilaku peserta didik yang hanya mengejar nilai semata tanpa memahami materi sejelas mungkin, hal ini senada dengan hasil wawancara dengan RA, "Kendala yang sering saya dan teman-teman temui itu saat mengerjakan tugas, seringnya guru hanya memberika tugas di tiap pertemuan, tanpa memberikan materi terlebih dahulu, kalaupun ada materi, itupun diberikan waktu awal semester saja, selanjutnya lebih sering diberi tugas dan disuruh untuk mencari materi sendiri, saya hanya belajar dengan menjawab tugas itu, setelah selesai mengerjakan tugas saya tidak mencari materi-materi IPS yang lain".

Masih dalam bingkai yang sama, guru juga terkadang memberikan materi ataupun tugas tidak sesuai dengan jam pelajaran IPS yang telah dijadwalkan, sehingga terkadang guru memberikan materi saat peserta didik sedang berada di jam pelajaran lain dan mengerjakan tugas dari mata pelajaran tersebut, hal ini menjadikan peserta didik semakin bingung karena terlalu banyak dibebani dengan tugas-tugas. Peserta didik memaknai pembelajaran IPS berbasis daring sebagai tugas online, karena setiap pertemuan hanya berujung pada pemberian tugas. Bahkan materi pembelajaran IPS yang diberikan selama ini sama sekali tidak dipahami oleh peserta didik, sebagaimana terungkap dari hasil wawancara dengan peserta didik berinisial RA, "Hal yang saya tangkap dan dapat selama pembelajaran 
daring IPS itu hanya tugas yang diberikan secara online saja, saya sangat kesulitan dalam memahami materi karena kan dulu seringnya dengerin guru berceramah memberikan materi di depan kelas tapi tiba-tiba daring seperti ini guru malah sama sekali tidak menjelaskan, hanya memberi materi itupun jarang dan lebih seringan tugasnya, padahal IPS itu kan materinya susah, jadi selama pembelajaran IPS ini saya seperti tidak mendapat ilmu atau materi apapun".

Motivasi belajar peserta didik terhadap pembelajaran IPS berbasis daring juga sangat rendah dan kurang, hampir seluruh peserta didik yang menjadi informan penelitian menyatakan bahwa mereka tidak pernah membaca ataupun mengulas materi mata pelajaran IPS karena memang tidak ada motivasi maupun semangat karena melihat guru yang justru terkesan kurang menarik dan memotivasi peserta didik dalam memberikan pembelajaran IPS.

\section{Solusi Terhadap Kendala Pembelajaran IPS Berbasis Daring Bagi Peserta Didik SMP Di Kecamatan Tahunan, Kabupaten Jepara}

Berbagai kendala dalam pembelajaran IPS berbasis daring yang dialami oleh peserta didik jenjang SMP di Kecamatan Tahunan, Kabupaten Jepara sangat kompleks. Dimulai dari permasalahan yang mendasar hingga permaslahan yang berkenaan langsung dengan proses penyampaian materi melalui media online. Kendala yang terjadi mengindikasikan tidak terlaksananya tujuan pembelajaran IPS bagi peserta didik. Tatkala pembelajaran daring, pembelajaran IPS yang sarat akan materi, konsep-konsep, dan fakta yang identik dengan hafalan harus disajikan oleh guru secara menyenangkan dan menarik motivasi peserta didik untuk giat belajar terutama dalam mata pelajaran IPS.

Di sisi guru, terdapat beberapa solusi maupun upaya yang dapat dilakukan secara mandiri maupun kolektif. Mandiri dalam artian guru IPS dapat meningkatkan kapasitas dan kemampuan dirinya mengenai penggunaan teknologi digital sebagai sarana penyampaian materi melalui media pembelajaran yang menarik, maksudnya dapat menarik minat dan motivasi peserta didik untuk semangat dan giat belajar mata pelajaran IPS. Penyampaian materi yang dilakukan oleh guru misalnya melalui google classroom harus lebih digencarkan lagi, materi jangan hanya terpaku pada buku digital saja, namun alangkah lebih baiknya jika sering menggunakan video pembelajaran, infografis, mind map, dan lain sebagainya agar tidak menimbulkan kebosanan pada peserta didik. Pada setiap pertemuan hendaknya diawali dengan do'a melalui rumah masing-masing, kemudian pemberian motivasi dan pesan untuk tetap menjaga kesehatan di tengah pandemi COVID-19 oleh guru kepada peserta didik, hal ini sekaligus menjadi pijakan dalam menanamkan ruh atau naluri akan kepedulian serta interaksi antar sesama kepada peserta didik.

Tugas yang diberikan kepada peserta didik juga harus berupa tugas yang berbasis pada pengembangan kompetensi dan keterampilan sosial dan berpikir kritis kepada peserta didik. Sehingga melalui tugas tersebut, dapat membentuk pribadi peserta didik yang melekat dengan dimensi serta tujuan pembelajaran IPS. Selain itu, sesekali ataupun beberapa kali guru melakukan pertemuan secara online misalnya melalui aplikasi zoom ataupun google meet untuk menjelaskan materi secara langsung kepada peserta didik. Satu hal yang tidak kalah pentingnya, guru juga harus menyelipkan pengetahuan dan penanaman akan literasi media atau literasi digital kepada peserta didik mengingat intensifnya peserta didik dalam mengakses gadget bahkan hampir tidak ada hari tanpa gadget dalam kehidupan peserta didik. Hal ini tak lain dan tak bukan agar peserta didik dapat menganalisis, memfilter atau menyaring segala informasi yang ada di media online secara kritis, serta terhindar dari segala dampak buruk akan penggunaan media online.

Disisi peserta didik dan orang tua, Sesibuk apapun orang tua dalam mencari pundipundi rupiah, orang tua harus tetap memberikan 
motivasi dan pendampingan kepada peserta didik tak peduli jika hanya sebentar saja di selasela kesibukannya. Mengingat pembelajaran daring identik dengan penggunaan gadget yang intensif sehingga peserta didik perlu diawasi dan didampingi oleh orang tua pada saat mengakses pembelajaran daring maupun pada saat diluar pembelajaran. Hal ini tak lain agar peserta didik tetap fokus dan disiplin dalam melaksanakan pembelajaran daring dan menyelesaikan tugas secara tepat waktu serta tidak menggunakan gadget untuk mengakses hal-hal yang sama sekali tidak berkorelasi dengan materi pembelajaran. Perlunya komunikasi antara guru dengan orang tua peserta didik selama pembelajaran daring untuk memberikan arahan agar senantiasa mendampingi peserta didik selama aktivitas belajar dari rumah.

\section{SIMPULAN}

Aktivitas pembelajaran IPS berbasis daring oleh peserta didik tingkat Sekolah Menengah Pertama (SMP) di Kecamatan Tahunan, Kabupaten Jepara dapat dikatakan belum berjalan secara optimal. Proses pembelajaran memang tetap dilakukan dengan menggunakan aplikasi pembelajaran online seperti google classroom. Namun masih terdapat banyak kendala yang dialami dari sisi peserta didik seperti jaringan internet yang kurang stabil, ketersediaan kuota internet yang kurang memadai, guru IPS lebih sering memberikan tugas dibandingkan dengan materi, peserta didik yang kurang memahami materi pembelajaran, dan berbagai kendala lainnya. Akibatnya, pencapaian tujuan pendididikan IPS dalam membentuk peserta didik menjadi warga negara yang baik (good citizen) serta berbagai tujuan yang lain misalnya menumbuhkembangkan pengetahuan, keterampilan, sikap, dan nilainilai pada diri peserta didik tidak terlaksana.

Kendati demikian, diperlukan upaya dari berbagai pihak agar pembelajaran IPS berbasis daring dapat terlaksana secara maksimal dan menorehkan hasil yang optimal. Guru IPS perlu melakukan inovasi dalam proses penyampaian materi pembelajaran IPS misalnya dengan memberikan media pembelajaran yang menarik dan interaktif. Tugas-tugas yang diberikan oleh guru juga harus berorientasi pada peningkatan kemampuan berpikir kritis dan keterampilan sosial peserta didik, hal ini sekaligus dapat dimaknai sebagai suatu pijakan dalam menumbuhkan keterampilan abad 21 yang harus dimiliki oleh peserta didik agar mampu berkolaborasi secara global.

\section{DAFTAR PUSTAKA}

Al Muchtar, S. 2014. Epistomologi Pendidikan IPS. Bandung : Wahana Jaya Abadi

Al Muchtar, S. 2014. Inovasi dan Transformasi Pembelajaran Pendidikan. Bandung : Gelar Pustaka Mandiri

Gunawan, R. 2013. Pendidikan IPS. Bandung : Alfabeta

Karnawati dan Mardiharto. (2020). Sekolah Minggu Masa Pandemi Covid-19: Kendala, Solusi, Proyeksi. Jurnal STT Simpson, 13-24 doi: 10.46445/djce.vlil.291

Kementrian Pendidikan Nasional. (2003). Sistem Pendidikan Nasional.

Sanjaya, W. 2013. Strategi Pembelajaran. Jakarta : Kencana

Santrock, J. W. 2013. Psikologi Pendidikan. Jakarta : Kencana

Siyoto, S., \& Sodik, A. (2015). Dasar Metodologi Penelitian. Yogyakarta: Literasi Media Publishing.

Supardan, D. 2015. Pembelajaran IPS. Bandung : Bumi Aksara

Susanto, Ahmad. 2016. Pengembangan Pembelajaran IPS di Sekolah Dasar. Jakarta: Prenadamedia Group

Somantri, M. N. 2001. Menggagas Pembaharuan Pendidikan IPS. Bandung : Rosda

Somantri, M. N. , dkk. 2010. Inovasi Pembelajaran 
Meta Febiani, dkk / Harmony 6 (1) (2021)

IPS. Bandung : Rizqi Press

World Health Organization. (2020).
"Coronavirus". Diakses pada taggal 9 Oktober2020.https://www.who.int/health -topics/coronavirus. 